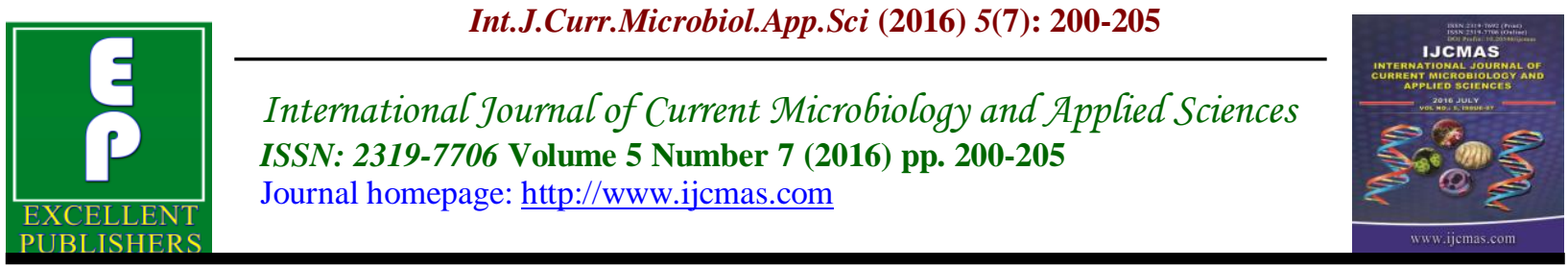

Original Research Article

http://dx.doi.org/10.20546/ijcmas.2016.507.020

\title{
Study of Bacteriological Profile of Corneal Ulcers in Patients Attending VIMS, Ballari, India
}

\section{S. Krishna, Qurath Saba*, J. Mariraj, Y.A. Surekha, Shafiya Bi, P. Divya and Sadiqa Begum}

\begin{abstract}
Department of Microbiology, Vijaynagar Institute of Medical Sciences, Ballari 583104, Karnataka, India

*Corresponding author
\end{abstract}

Keywords

Corneal ulceration,

Corneal scraping,

Antimicrobial susceptibility testing, Gram positive cocci, Gram negative bacilli.

\section{Article Info}

Accepted:

12 June 2016

Available Online:

10 July 2016

\section{A B S T R A C T}

Corneal infection is leading cause of ocular morbidity and blindness worldwide. Identification of the pathogen, initiation of immediate therapy based on the organism identified represent the keys to success in management of corneal ulcers. Aim of this study is to define the bacteriological profile of corneal ulcers and to test their in-vitro bacterial susceptibility. Patients presenting with suspected bacterial corneal ulceration 2015 were included. Corneal scraping was performed and processed for direct microscopy, and bacteriological culture. Antimicrobial susceptibility testing was done according to CLSI guidelines. Of 300 specimens examined, $62(20.7 \%)$ had bacterial growth. Gram positive cocci were comprised of $43(69.4 \%)$ and gram negative bacilli $19(30.6 \%)$. The commonest bacterial pathogen isolated was Staphylococcal aureus 28(45.2\%), followed by Coagulase Negative Staphylococci 8 (12.9\%) and Streptococcus 7(11.21\%). Pseudomonas spp $5(8.1 \%)$ and E.coli 5 (8.1\%). Staphylococcus aureus and E.coli were $100 \%$ susceptible and all other strains were $>80 \%$ susceptible to gentamycin and amikacin. Staphylococcus spp. were the most common bacterial pathogens isolated from patients with corneal ulcers in this institute. High percentages of gram-positive and gram-negative bacteria were susceptible to aminoglycosides. So, these drugs appear to be the therapy of choice for corneal ulcers. Routine microbiological examination of corneal ulcer is necessary to analyze the microbial etiology and to treat them with appropriate antibiotics to prevent further complications.

\section{Introduction}

Corneal infection is leading cause of ocular morbidity and blindness worldwide. Corneal ulceration is a major cause of monocular blindness in developing countries. Corneal scarring listed second only to cataracts as an important cause of blindness and visual impairment in many developing countries in 
Asia, Africa and the Middle East (Amatya et al., 2012). The avascular corneal stroma is particularly susceptible to bacterial infection, and many patients have a poor clinical outcome if aggressive and appropriate therapy is not promptly initiated.

Corneal perforations, which can occur in less than 24 hours, have been reported in the presence of particularly invasive pathogens such as Pseudomonas aeruginosa and Staphylococcus aureus (Schaefer et al., 2001). The bacterial sensitivity to various antimicrobial agents varies from place to place and in the same place from time to time (Sharma et al., 2011; Bharathi et al., 2010). Identification of the pathogen, initiation of immediate therapy based on the organism identified represent the keys to success in management of corneal ulcers.

The main objectives of this study to define the bacteriological profile of corneal ulcers. And to test their in-vitro bacterial susceptibility.

\section{Materials and Methods}

Patients presenting with suspected bacterial corneal ulceration were included. Total of 300 corneal scraping samples were collected for the study.

\section{Inclusion Criteria}

Patients presenting with suspected infectious bacterial corneal ulceration were included in this study.

\section{Exclusion Criteria}

Patients suspected of having or with a positive culture for fungal, viral, or parasitic infection were excluded.

\section{Sample Collection}

Material was obtained under topical anaesthesia (4\% lignocaine hydrochloride) by scraping the base and edges of the ulcerated part of the cornea under the magnification of a slit lamp by an ophthalmologist using a sterile platinum spatula or a sterile Bard-Parker knife (Ptricia et al., 2013; Kaliamurthy et al., 2013). Samples were immediately inoculated onto slides for gram staining and microscopy, and onto blood or chocolate agar plates, and Sabouraud agar plates (in that order) for culture (Orlans et al., 2011; Tesfaye et al., 2013), and sent to microbiology laboratory for processing.

\section{Sample Processing}

$\mathrm{KOH}$ mount and gram staining was performed. Depending on the type of growth, various biochemical tests were performed to identify the pathogen. In vitro Antimicrobial susceptibility testing was done according to CLSI guidelines, by the standard agar discdiffusion method (Kirby-Bauer) on Mueller Hinton agar (Pachigolla et al., 2007; Orlans et al., 2011).

\section{Results and Discussion}

Of 300 specimens examined, 62(20.7\%) had bacterial growth. The mean age of the patients was of 38.5 years (range 3-80 years) of 62 patients, $36(58.1 \%)$ were males, and $26(41.3 \%)$ were females (fig 1).

Among growth positive cases, most common isolates were gram positive cocci, comprising of $43(69.4 \%)$, followed by gram negative bacilli 19(30.6\%)(fig 2). The commonest bacterial pathogen isolated among gram positive cocci was Staphylococcal aureus 28(45.2\%), followed by Coagulase Negative Staphylococci 8 
(12.9\%) and Streptococcus 7(11.21\%) (fig $3)$.

Among gram negative bacilli most common organism were Pseudomonas spp 5(8.1\%) and E.coli 5(8.1\%). Klebsiella and Citrobacter were 2(3.2\%), non fermenting GNB 4(6.4\%), Enterobacter 1(1.6\%) (fig 4).

Staphylococcus aureus and E.coli were $100 \%$ susceptible to gentamycin and amikacin. All other isolates were $>80 \%$ susceptible to gentamycin and amikacin.

$80 \%$ Pseudomonas were resistance to amoxycillin clavulinic acid combination, while $30.4 \%$ S.aureus were so. GPCs were susceptible to most of the drugs as compared to GNBs.

Corneal ulceration is a major cause of monocular blindness in developing countries. Bacterial keratitis is a potentially devastating ocular infection that may occur when the corneal epithelial barrier is compromised due to injury or trauma, leading to ulceration and infiltration of inflammatory cells

This study focuses on to the pattern of bacterial pathogens causing corneal ulcers and their antibiogram among patients who attended VIMS, Ballari. Infection largely involves gram-positive cocci such as, S.aureus, CONS and Streptococcus spp, as well as gram-negative bacteria such as Ps.aeruginosa. In this study, gram-positive cocci accounted for 43 of $62(69 \%)$ bacterial isolates. This result is comparable to the $77 \%$ in a study done by $\mathrm{J}$ Kaliamurthy et al, and $52.0 \%$ in study by $\mathrm{T}$ Tesfaye et al in Ethiopia. Predominant among GPC is S.aureus $45.2 \%$, which is consistent with studies done by $\mathrm{T}$ Tesfaye, $\mathrm{R}$ Amatya, $\mathrm{HO}$ Orlans which showed $54.5 \%, 44.5 \%$ and $40.1 \%$ S.aureus respectively.

Among GNB, Pseudomonas was common in this study accounting for $8.1 \%$, which is almost similar to $9.38 \%$ in the study done by R Amatya et al.

Fig.1 Sex Ratio

$42 \%$

$58 \%$ 
Int.J.Curr.Microbiol.App.Sci (2016) 5(7): 200-205

Fig.2 Organism Ratio

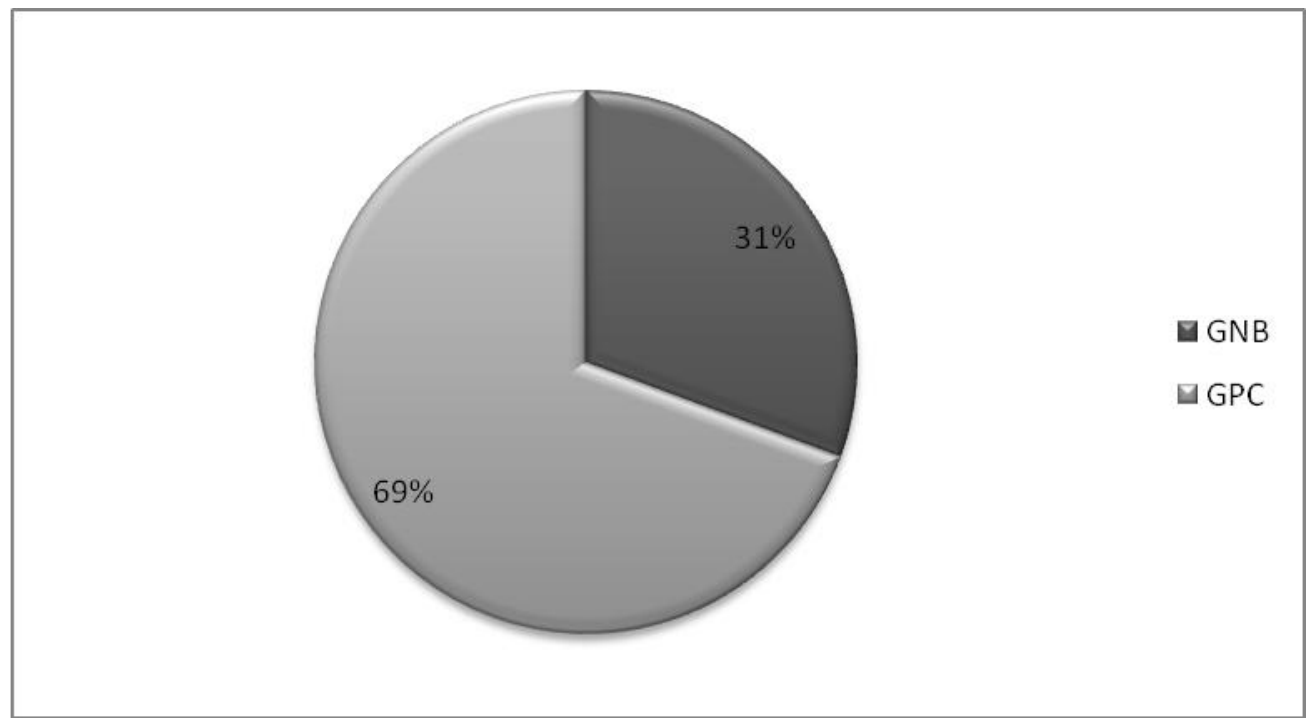

Fig.3 Percentage of Gram Positive Isolates

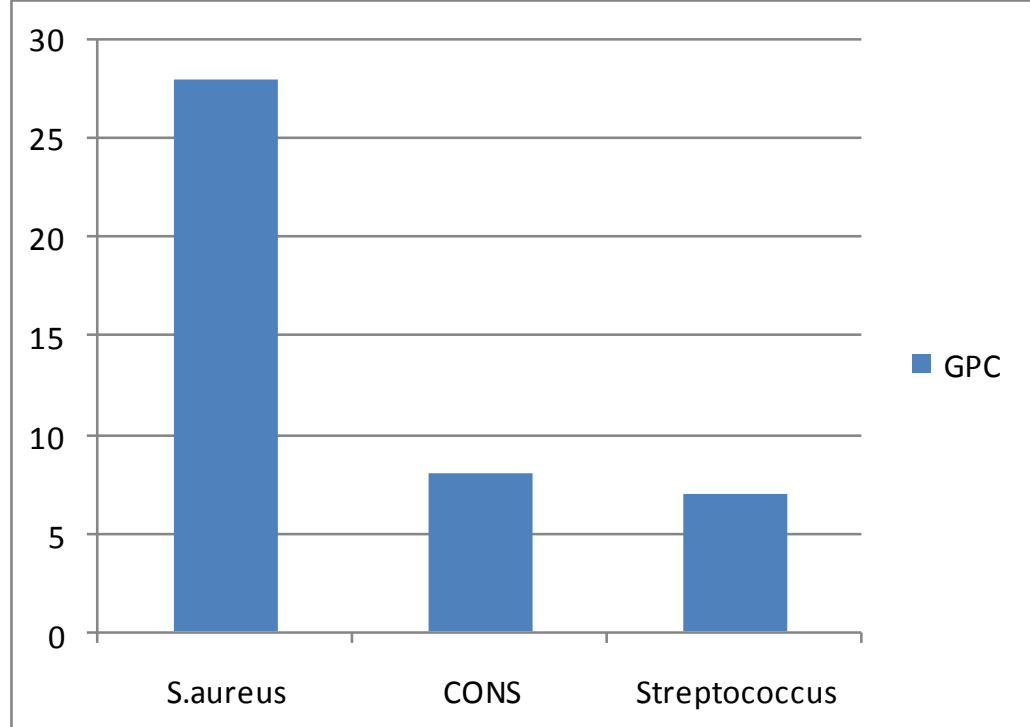


Fig.4 Percentage of Gram Positive Isolates

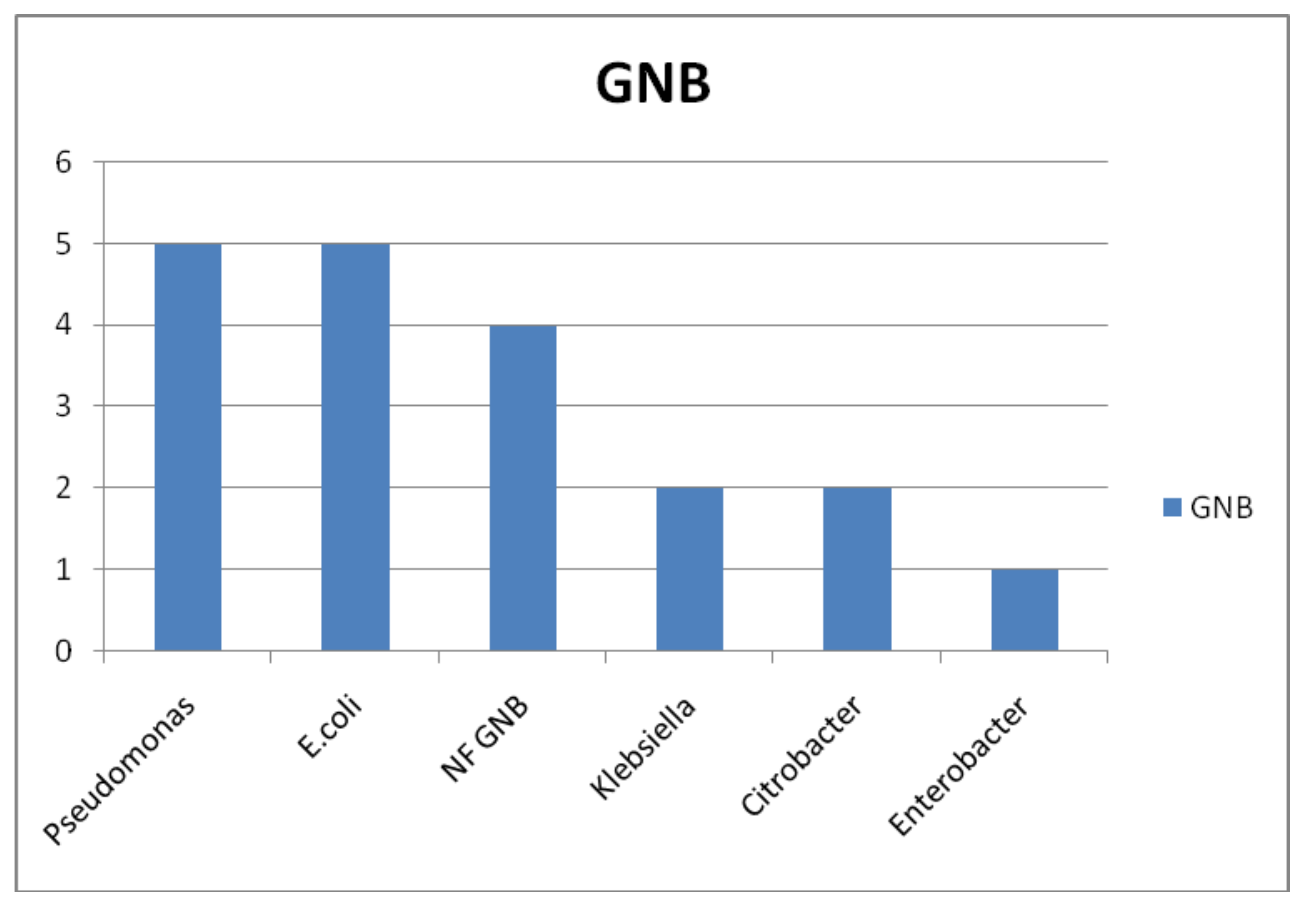

Almost all the organisms were highly susceptible to gentamycin and amikacin.

S.aureus was $100 \%$ susceptible to gentamycin and amikacin, $83 \%$ to cefriaxone, $72 \%$ to cefotaxime, $70 \%$ to amoxycillin clavulinate, $64 \%$ to ciprofloxacin.

Pseudomonas was $80 \%$ susceptible to aminoglycosides, followed by ciprofloxacin $75 \%$ and cefotaxime $60 \%$. This was consistent with study done by J Kaliamurthy et al susceptible to amikacin $(89.7 \%)$, gentamicin $(89.7 \%)$, ciprofloxacin $(82.9 \%)$. E.coli was $100 \%$ susceptible to gentamycin and amikacin, followed by ceftriaxone $75 \%$.

In conclusion, gram positive cocci especially, Staphylococcus spp. were the most common bacterial pathogens isolated from patients with corneal ulcers in this institute. Among gram negative organisms, Pseudomonas, E.coli were common pathogens. High percentages of gram- positive and gram-negative bacteria were mostly susceptible to aminoglycosides. So, these drugs appear to be the therapy of choice for corneal ulcers. Routine microbiological examination of corneal ulcer is necessary to analyze the microbial etiology and to treat them with appropriate antibiotics to prevent further complications.

\section{Acknowledgement}

The authors would like to acknowledge all teaching and nonteaching staff of the hospital for their assistance.

\section{References}

Amatya, R., et al. 2012. Etiological agents of corneal ulcer: five years prospective study in eastern Nepal. Nepal Med Coll J., 14(3): 219-222.

Bharathi, M.J., et al. 2010. Etiology and antibacterial susceptibility pattern of community-acquired bacterial ocular 
infections in a tertiary eye care hospital in south India. Indian J. Ophthalmol., 58(6): 497-507.

Kaliamurthy, J., et al. 2013. Spectrum of Bacterial Keratitis at a Tertiary Eye Care Centre in India. Bio Med. Res. Int., Article ID181564, 8pgs.

Orlans, H.O., et al. 2011. In vitro antibiotic susceptibility patterns of bacterial keratitis isolates in Oxford, UK: a 10year review. Eye, 25: 489-493.

Pachigolla, G. et al. 2007. Microbial keratitis pathogens and antibiotic susceptibilities: a 5-year review of cases at an urban county hospital in North Texas. Eye and Contact Lens, vol.33, no.1, pp.45-49.
Ptricia, M., Tille. 2013. Bailey and Scott's Diagnostic Microbiology; 13th ed. (Elsevier Health Sciences, US).

Schaefer, F., et al. 2001. Bacterial keratitis: a prospective clinical and microbiological study. $\mathrm{Br} \quad J$ Ophthalmol., 85: 842-847.

Sharma, S. 2011. Antibiotic resistance in ocular bacterial pathogens. Indian $J$. Med. Microbiol., 29: 218-222.

Tesfaye, T., et al. 2013. Bacterial Profile and Antimicrobial Susceptibility Pattern of External Ocular Infections in Jimma University Specialized Hospital, Southwest Ethiopia. American $J$. Infect. Dis. Microbiol., Vol.1,No.1:1320.

\section{How to cite this article:}

Krishna, S., Qurath Saba, J. Mariraj, Y.A. Surekha, Shafiya Bi, P. Divya and Sadiqa Begum. 2016. Study of Bacteriological Profile of Corneal Ulcers in Patients Attending VIMS, Ballari, India. Int.J.Curr.Microbiol.App.Sci. 5(7): 200-205. doi: http://dx.doi.org/10.20546/ijcmas.2016.507.020 